\title{
Leaders for the Banking Industry: An Investigation on Effective Leadership
}

\author{
U.L.T.P. Gunasekare \\ Faculty of Commerce and Management Studies, \\ University of Kelaniya, Sri Lanka
}

thamarag@kln.ac.lk

Abstract
Leadership is critical in achieving performance and yet not exhausted, keeping
scholars to uncover more findings on effective leadership styles. This study
expected to identify the effective leadership style for enhanced employee
performance in the banking industry in Sri Lanka. The banking industry has a
unique work environment that stresses performance targets, long working hours,
and error-free transactions while making the customers happy. Thus, leadership is
a critical stimulus that this study focused on. The findings illustrate that
transformational leadership style is the most present style among the bankers in
Sri Lanka, and employee performance is above average with transformational
leaders. Overall, scores in the transformational leadership style were found to be
strongly correlated with employee performance. The results suggest that
supervisors in the banking sector need to use a lot of transformational leadership
behaviours or rather embrace a transactional leadership style. The implications of
the study are significant in HR practices like recruiting and training managers as
leaders in the banking sector.
Keywords: leadership style, transformational leadership, MLQ, transactional
leadership, employee performance

JEL $\quad$ : M10

DOI $\quad: 10.24002 /$ kinerja.v25i1.4048

Received : 01/06/2021 Reviewed: 02/11/2021 Final Version: 03/09/2021 


\section{INTRODUCTION}

Leadership is increasingly acknowledged as an exceptional tool that influences employee performance. An effective leader has the responsibility to provide guidance and lead employees for better performance. Therefore, the importance of leadership in achieving optimum organizational performance, which can hardly be overstated. Earlier leadership studies (Lewin, Lippit, \& White, 1939; Blake \& Mouton, 1964) tried to identify effective leadership styles and relate them to various aspects of organizational outcomes. The literature on leadership and employee performance is scattered across countries and across industries, while the evidence of the effect of leadership style on employee performance is also varied (Bass, 1990). Contemporary leadership literature has discussed modern leadership theories like transactional, transformational, and charismatic leadership, focusing on their effects on various organizational factors specially followers' motivation, follower satisfaction, and performance (Avolio, 1999; Bass, 1985; Bass \& Avolio, 1994, 1997; Conger \& Kanungo, 1987; Lowe \& Gardner, 2000). Hunt (1999) further attributed the upgrading and continued interest in leadership research to the transactional, transformational, and charismatic leadership models that were emerging in the literature during the mid-1980s and in the 1990s, which were being tested throughout the educational, psychological, and management literatures (Mccleskey, 2014).

Since leadership is a key factor for improving employee performance of an organization, the excellent performance of an organization depends on the effectiveness of leadership at all levels (Randall, 2012). Precisely, managers show diverse a range of leadership styles when they are practicing management (Vigoda-Gadot, 2007). Managers in the banking sector also follow a certain leadership style that clearly affects bank performance. In other sense their leadership style is directly linked to bank performance.

In Sri Lanka, the banking sector is performing a key role in directing public deposits to investment, consumption, and lending that eventually assists in improving the standard of living and quality of life of the citizens of the country (CBSL,2018). Banking, however, is a special feature of the economic life of Sri Lanka. In the new era of globalization, the banking sector has witnessed drastic changes at the structural and organizational levels. In the financial sector, banks act as catalysts for economic growth, and it is clear that nations who have good financial systems have a tendency to develop its economic growth more quickly (Ojokuku, Odetayo, \& Sajuyigbe, 2012). In this way, banks play a key role in an economy, requiring the performance of a bank at the top priority. Deciding the best business practices in developing new markets and clients, and creating new products within e-commerce and net-based technologies, retain bank performance more competitive. The banking sector in Sri Lanka is mainly denoted by licensed commercial banks (LCB) and licensed special banks (LSB). Licensed savings banks represent development banks, savings banks, and housing finance institutions. These two types are major in the Sri Lankan banking sector. Therefore, 
this research is based on these two types (licensed commercial banks (LCB) and licensed special banks (LSB)) Sri Lanka.

The objective of this study is to study the leadership styles of bank managers and identify the impact of leadership style on bank performance in Sri Lanka. As supplement the studies already done in this line of study, the current study intends to suggest leadership interventions that are highly correlated with bank performance in the Sri Lankan banking sector. Further, the findings will impart the knowledge of leadership literature by way of uncovering the impactful leadership for the banking industry in Sri Lanka. Despite recent academics focusing on the relationship between bank performance and most of the economic indicators, there is a remarkable absence of satisfying analysis in the literature, and how bank leadership style determines the bank performance. It is generally left unspecified whether the relationship between bank leaders and bank performance. Since it is the soft aspect of bank performance which imparts employee performance, the implication will help to choose the appropriate leadership, which may be quite different to turn the banks' performance competitive.

According to Hunt (1999) work on transactional and transformational leadership in particular is described as the start of the evolution of new theories in leadership. In this stage, theories are critically reviewed and, therefore, the focus was on identifying determiners, moderators, and mediators relevant to these leadership styles (Mccleskey, 2014;Johns \& Moser, 2001). The studies of leadership, however, in recent years, especially under the modern leadership paradigm, were dominated by transformational leadership and transactional leadership (Burns 1978; Bass 1985; Buciuniene and Skudience 2008) and other related new theories. Most of the literature reviewed for this study were somehow consistent in suggesting that both transformational and transactional leadership styles are significantly positively related to employee performance(Jing \& Avery, 2008:Ojokuku et al., 2012) And, more over the effect of transformational style is more pronounced than that of the transactional leadership style (Rasool et al., 2015; Kehinde and Bajo, 2014; Tsigu and Rao, 2015). Hence, this study tries to probe, between these two styles out of which style is the most impactful leadership style among managers in the banking sector in Sri Lanka.

\section{LITERATURE REVIEW}

\subsection{Transformational Leadership}

The concept of transformational leadership was introduced by James Macgregor Burns in 1978 in his descriptive research on political leaders, but its usage has spread into organisational psychology and management with further modifications by B.M Bass and J.B Avalio (Jung \& Sosik, 2002). Burns (1978) operationalized the theory of transformational leadership as one of the leadership styles represented in that period. A transformational leader is a person who 
stimulates and inspires (transform) followers to achieve extraordinary outcomes (Robbins and Coulter, 2007). He/she pays attention to concerns and developmental needs of individual followers, they change followers' awareness of issues by helping them to look at old problems in a new way; and they are able to arouse, excite, and inspire followers to put out extra effort to achieve group goals (Bass, 1997). Transformational leadership theory is all about leadership that creates positive change in the followers whereby they take care of each other's interests and act in the interests of the group as a whole (Warrilow, 2012).

Transformational leadership enhances the motivation, morale, and performance of followers through a variety of mechanisms (Manzoor et al., 2019). These include connecting follower's sense of identity and self to the project and the collective identity of the organization; being a role model for followers that inspires them and makes them interested; challenging followers to take greater ownership for their work, and understanding the strengths and weaknesses of followers, so the leader can align followers with tasks that enhance their performance (Kuhnert, Karl W., Lewis, 1987). Similarly, transformational leadership affects followers to feel more confident to perform beyond expectations by increasing the emotional connection or identification between the supervisor and the follower. Thus, leaders have positive effect on follower's performance (Arif, 2018). Bass (1985) identified four components of transformational leadership style: 1) Charisma or idealised influence: the degree to which the leader behaves in admirable ways and displays convictions and takes stands that cause followers to identify with the leader who has a clear set of values and acts as a role model for the followers. (2) Inspirational motivation: the degree to which the leader articulates a vision that is appeals to and inspires followers with optimism about future goals and offers meaning for the current tasks in hand. (3) Intellectual stimulation: the degree to which the leader challenges assumptions, stimulates and encourages creativity in the followers by providing a framework for followers to see how they connect [to the leader, the organisation, each other, and the goal] they can creatively overcome any obstacles in the way of the mission. (4) Individualized consideration: the degree to which the leader attends to each individual follower's needs and acts as a mentor or coach and gives respect to and appreciation of the individual's contribution to the team. This fulfils and enhances each individual team members' need for self-fulfilment and self-worth, and in so doing inspires followers to further achievement and growth (Russell, 2017). Like most leadership theories, transformational leadership theory assumes the heroic leadership stereotype (Johns \& Moser, 2001). Effective performance by an individual, group, or organization is assumed to depend on leadership by an individual with the skills to find the right path and motivate others to take it (Bass, Avolio, Jung, \& Berson, 2003). In most versions of transformational leadership theory, it is a basic postulate that an effective leader will influence followers to make self-sacrifices and exert exceptional effort (Li et al., 2019). The influence is unidirectional, and it flows from the leader to the follower (Mccleskey, 2014). When a correlation is found between transformational leadership and subordinate commitment or performance, the results are interpreted as showing 
that the leader influences subordinates to perform better. There is little interest in describing reciprocal influence processes or shared leadership. Researchers study how leaders motivate followers or overcome their resistance, not how leaders encourage followers to challenge the leader's vision or develop a better one. Despite the numerous criticisms of transformational leadership, its popularity has grown in recent times (Yukl, 1999). For instance, studies have shown that managers in different settings, including the military and business, found that transformational leaders were evaluated as more effective, higher performers, more promotable than their transactional counterparts, and more interpersonally sensitive (Rubin et al, 2005; Judge and Bono, 2000). Empirical evidence also shows that transformational leadership is strongly correlated with employee work outcomes such as lower turnover rates, higher levels of productivity, employee satisfaction, creativity, goal attainment, and follower well-being (Garcl'a-Morales et al, 2008; Piccolo and Colquitt, 2006; Keller, 1992). Leaders better to adopt the transformational leadership style by focusing on creating an innovative environment in the organization (Ali \& Chin-hong, 2018). However, leaders while inspiring and motivating their followers should not ignore their emotions. Moreover, followers should understand the shared values of the leader (Tahir, 2015).

\subsection{Transactional Leadership}

Transactional leadership is based on transactions between leaders and followers (Dinh et al., 2014). According to a transactional leader, human relations are nothing but a chain of transactions. The roots of this leadership style are reward, penalty, economic exchange, emotional and physical exchanges, and other such "transactions". To understand this leadership style in a simple way, just need to think like the leader leads the organization and tell followers what is their duty because s/he gets salary for it (Waldman, Bass, \& Yammarino, 1988). If the followers, to their duty efficient, they will get rewards and to failures, they get punishments. This is how a transactional leader leads the groups. This leadership is also recognized as managerial leadership (Kuhnert, Karl W., Lewis, 1987) because the center of attention of this leadership style is on the responsibility of administration, organization, and group performance. Transactional leadership is a style of leadership in which the leader encourages the observance of his followers through both rewards and punishments (Bass, 1997). Transactional leaders lead to uphold the chain of rules and regulations, but their approach is not looking to change the future(Alqatawenh, 2018). Transactional leaders apply a substitute model, where rewards are given for good outcomes or positive results. Transactional leaders are also capable of giving punishments for poor efforts or unsatisfactory outcomes (Hargis et al, 2001).

Transactional leadership, also known as managerial leadership, focuses on the role of supervision, organisation, and group performance; transactional leadership is a style of leadership in which the leader promotes compliance of his followers through both rewards and punishments (Meindl, 1993). Unlike transformational leadership, leaders using the transactional approach are not 
looking to change the future; they are merely looking to keep things the same (Judge \& Piccolo, 2004). These leaders pay attention to followers' work in order to find faults and deviations. This type of leadership is effective in crisis and emergency situations as well as when projects need to be carried out in a specific fashion (Tahir, 2015). Transactional leaders use an exchange model, with rewards being given for good work or positive outcomes. Conversely, people with this leadership style can also punish poor work or negative outcomes until the problem is corrected (Tahir, 2015). Transactional leaders are effective in getting specific tasks completed by managing each portion individually (Yaslioglu \& Selenay Erden, 2018).

\subsection{Organizational Performance}

Organizational performance is one of the most popular terms in today's especially both private and public-sector management. The idea of managing organizational performance is being extensively accepted and adopted all over the world. Performance is referred to as being about doing the work as well as being about the results achieved (Tahir, 2015). Organizational performance and measurements can be defined as the outcomes of work because they offer the strongest linkage to the strategic goals of an organization, customer satisfaction, and economic contributions (Corvellec, 2011). Organizational performance depends heavily on employee performance. Employee performance has been shown to have a significant positive effect on organizational performance (Bass \& Riggio, 2006). Employee performance in the banking sector generally reflects the individual performance of employees. Employee performance is defined as the jobrelated activities expected by the employer and how well those activities were executed. Individual performance has been critical in achieving organizational objectives as a strategy (Amos et al., 2004). Employee performance has been a critical issue in the modern business environment. (Baron et al., 2014). There are number of other factors that may affect individual employee performance such as manager's attitudes and their leadership styles, organizational culture, personnel problems, job content, and financial rewards. Among them, this study examines how leadership style affects employee performance (Arif, 2018).

\subsection{Relationship between Leadership Style and Employee Performance}

According to the studies on the relationship between leadership style and employee performance, it was found that transformational leadership behaviors, positively related to followers' job performance (Bono \& Judge, 2004). Furthermore, Nemanich and Keller (2007) concluded that transformational leadership behaviors had a significantly positive relationship with goal clarity, creative thinking, and follower performance. The authors suggest that transformational leadership is used to face challenges, such as those encountered during an acquisition (Riad Ahmad Mohammed Abazeed, 2018). A similar study by Piccolo and Colquitt (2006) found that leaders' transformational behaviors, had a significantly positive relationship with task performance. Further they also found 
intrinsic motivation and goal commitment to significantly mediate the relationship between transformational leadership behaviors and task performance. Moreover, it was found that the leader member exchange fully mediates the relationship between transformational leadership and task performance (Wang, Chich-Jen, \& Mei-Ling, 2010). According to Mehra et al. (2006), when some organizations seek efficient ways to enable them to outperform others, a longstanding approach is to focus on the effects of leadership. Hence, past studies proved that leadership style significantly impacts employee performance. Manzoor et al., in 2019 have explored the pact of transformational leadership on job performance and CSR as a mediator in the SMEs context in Pakistan. Their findings revealed that the transformational leadership and CSR activities have a positive association with job performance, and it was also identified that CSR have a positive and affirmative mediating influence in the relationship between transformational leadership and job performance (Manzoor et al., 2019).

\section{METHODOLOGY}

In this study, the conceptual framework put emphasizes on the transformational leadership (idealized influence, inspirational motivation, and intellectual stimulation), transactional leadership styles (contingent reward and management by exception), and employee performance. The strength and direction of the relationship were measured to identify the type and intensity of the relationship. The study adopted a survey research design. Convenience sampling of respondents was used, and this was a quantitative study to allow for descriptive and inferential analysis. The full range leadership model assumes that every leader displays each style to some degree within a range of leadership styles ranging from laissez-faire to transformational leadership. But in this study, the consideration was given only to transactional leadership and transformation leadership, except laissezfaire leadership. According to Northouse (2015) laissez-faire leadership is actually considered as the absence of leadership. To measure the leadership style, the Multi-factor Leadership Questionnaire (MLQ) rater version was employed among the bank tellers, customer care staff, back-office staff, credit officers, and relationship officers. The categories chosen were thought to be involved in bank's operational activities and reporting to the bank leadership. The researcher formulated questionnaires to obtain data regarding age, gender, education levels, and length of service in the organization, which helped in understanding the respondents' background information. Employee performance was depended variable, measured by the performance scale developed by Yousef (2000).

\section{RESULT AND DISCUSSION}

Two main types of leadership styles were assessed. They were transformation leadership style with four dimensions (each with three items), and transactional 
leadership style with two dimensions (each with three items). Descriptive statistics were used to assess how far the managers of the banking sector exercise the transformational leadership style. Table 1 presents the results of the transformational leadership style. The mean and standard deviation (S.D.) of the four dimensions of transformational leadership styles were calculated to establish the respondents' assessment of the extent to which their immediate supervisors' practices transformational leadership style. The scale used in the statements were given values as, 1-strongly disagree, 2-disagree, 3-neutral, 4-agree, and 5-strongly agree.

Table 1. Results of Transformational Leadership

\begin{tabular}{lcc}
\hline Dimensions & Mean & Standard deviation \\
\hline Intellectual Simulation. & 4.41 & 0.604 \\
Idealized Influence & 4.30 & 0.556 \\
Inspirational Motivation & 3.57 & 0.586 \\
Individual Consideration & 3.24 & 0.564 \\
Transformational leadership & 4.10 & 0.564 \\
\hline
\end{tabular}

Source: Survey data

The results show in Table 1 indicate that the Intellectual Simulation had the highest mean of 4.41 and standard deviation of 0.604 , followed by Idealized Influence at a mean of 4.30 and standard deviation of 0.556 . Inspirational Motivation had a mean of 3.57 and standard deviation of 0.586 . The least but still with a high mean of 3.24, and the standard deviation of 0.564 was the dimension of Individual Consideration. Overall, the transformational leadership style scored a mean of 4.10 and S.D. of 0.564 .

Table 2. Results of Transactional Leadership

\begin{tabular}{lcc}
\hline \multicolumn{1}{c}{ Dimension } & Mean & Standard Deviation \\
\hline Management by Exceptions & 3.392 & 0.604 \\
Contingent Rewards & 2.161 & 0.766 \\
Transactional Leadership & 3.052 & 0.772 \\
\hline
\end{tabular}

Source: Survey data

In analyzing transactional leadership, Table 2 shows that management by exception had the highest mean of 3.392 and standard deviation of 0.604 , while contingent reward had a mean of 2.161 and standard deviation of 0.766 . Overall, the results show that transactional leadership style with an overall mean score of 3.052 and standard deviation of 0.772 . In fact, it is important to note that the mean score was above the midpoint. These statistics indeed show that supervisors in banks apply transformational leadership. 
Employee performance (self-rated) was captured by two constructs: quality and productivity. The results in Table 3 show that the quality of performance was highly rated with a mean of 4.432 and a standard deviation of 0.622 , while productivity was closely followed with a mean of 4.231 and a standard deviation of 0.584 . Overall employee performance had a mean score of 4.263 and a standard deviation of 0.621 , indicating a high performance. This is then subjected to further analysis in the next section to determine whether it is affected by the employees' perception of the leadership style of the immediate supervisor.

Table 3. Results of Performance

\begin{tabular}{lcc}
\hline \multicolumn{1}{c}{ Dimension } & Mean & Standard Deviation \\
\hline Quality & 4.432 & 0.622 \\
Productivity & 4.231 & 0.584 \\
Performance & 4.263 & 0.621 \\
\hline
\end{tabular}

Source: Survey data

Table 4. Correlation between Transactional Leadership and Employee Performance

\begin{tabular}{lc}
\hline & $\begin{array}{c}\text { Correlation between Transactional Leadership } \\
\text { and Employee Performance }\end{array}$ \\
\hline Pearson Correlation & $0.578^{* *}$ \\
\hline Sig. (2-tailed) & 0.000 \\
\hline $\mathrm{N}$ & \\
\hline
\end{tabular}

Note: ${ }^{*}$ Correlation is significant at the 0.01 level ( 2 tailed)

Source: Survey data

Table 4 presents the results of Pearson correlation statistics. There is a positive correlation between two variables at a significance level of 0.01 (Two tailed test). Accordingly, it indicates a moderate positive relationship (0.578) between transactional leadership and employee performance.

Table 5 Correlation between Transformational Leadership and Employee Performance

\begin{tabular}{lc}
\hline & $\begin{array}{c}\text { Correlation between Transformational } \\
\text { Leadership and Employee Performance }\end{array}$ \\
\hline Pearson Correlation & $0.878^{* *}$ \\
\hline Sig. (2-tailed) & 0.000 \\
$\mathrm{~N}$ & \\
\hline Note: ${ }^{* *}$ Correlation is significant at the 0.01 level (2 tailed) \\
Source: Survey data
\end{tabular}


Table 5 shows how far the transformational leadership correlates with employee performance. In summary, the results of the correlation analysis indicated that transformational leadership has a strong and positive correlation with employee's performance.

Table 6. Regression Coefficients

\begin{tabular}{|c|c|c|c|c|c|}
\hline \multirow[t]{2}{*}{ Model } & \multicolumn{2}{|c|}{$\begin{array}{l}\text { Unstandardized } \\
\text { Coefficients }\end{array}$} & \multirow{2}{*}{$\begin{array}{c}\text { Standardized } \\
\text { Coefficients } \\
\text { Beta }\end{array}$} & \multirow[b]{2}{*}{$\mathbf{t}$} & \multirow[b]{2}{*}{ Sig. } \\
\hline & B & $\begin{array}{l}\text { Std. } \\
\text { Error }\end{array}$ & & & \\
\hline $\begin{array}{l}1 \text { (Constant) } \\
\text { Transactional }\end{array}$ & 2.562 & 0.482 & & 5.540 & 0.000 \\
\hline $\begin{array}{l}\text { Leadership } \\
\text { Transformational }\end{array}$ & 0.247 & 0.074 & 0.219 & 2.325 & 0.000 \\
\hline Leadership & 0.752 & 0.105 & 0.478 & 4.921 & 0.002 \\
\hline
\end{tabular}

Note: Dependent variable is Employee Performance Source: Survey data

Regression analysis was carried out to estimate the effect of leadership styles (independent variables) on employee performance (dependent variable). Table 6 presents the results of the coefficient of the regression model. The coefficient results show that transformational leadership positively predicts employee performance with standardized Beta $=0.478,(p<0.01)$. These results suggest that the performance of employees whose immediate supervisor exhibited transformational leadership characteristics increased significantly by $47.8 \%$.

\section{CONCLUSION}

The findings show that the transformational leadership style is the most exhibited style at the banks in Sri Lanka. With the presence of transformational leadership, employee performance is above average. Overall, scores in transformational leadership style were found to be strongly correlated with both measures of employee performance (quality and productivity) and overall performance too. Odumeru and Ogbonna (2013) state that transformational leadership enhances the motivation, morale, and performance of followers through a variety of mechanisms (Odumeru \& Ogbonna, 2013). Further, the results of the current study suggest that transactional leadership has a positive effect on the employee performance, but it is not as much strong as the transformational leadership style, which means that the more an organization is inclined toward transformational leadership, the stronger the employee performance. On the other hand, transactional leadership style has a positive effect on the performance of 
employees, which means that transactional leadership style is also accepted by the followers to yield performance. The study intended to examine the leadershipperformance relationship in the banking sector in Sri Lanka and, thus, contribute meaningfully to the body of growing literature and knowledge in this area of study. Accordingly, the findings conclude that in the Sri Lankan banking sector, quality and productive employee performance can be achieved mostly through transformational leadership orientations, but transactional leadership also produces better performance. With these findings, it further gives emphasis to the followers' aspirations about their leaders. Banking staff like bank tellers, customer care staff, back-office staff, credit officers, and relationship officers are able to work with either type of leader. Nevertheless, transformational leaders have more capacity to have an effect on their followers for better performance. Managerial Implication

\subsection{Managerial Implication}

There are implications in this study to HR practices in banks. HR managers can look for more transformational leadership features in recruiting, selection, and promotion decisions. Managerial training and development interventions should be prepared in such a way that the training managers gain more transformational physiognomies via these programs. Since transformational leadership results higher performance, the emphasis should be given on such characteristics in their employees of higher positions in banks.

\section{REFERENCE}

Amos, T.L., Ristow, A. and Ristow, L. (2004), Human Resource Management (2nd Edition). Lansdowne: Juta and Co Ltd.

Ali, M., \& Chin-hong, P. (2018). Transformational Leadership, Organizational Commitment and Innovative Success. Market Forces, College of Management Sciences, (88134).

Alqatawenh, A. S. (2018). Transformational leadership style and its relationship with change management. Business: Theory and Practice, 19, 17-24. https://doi.org/10.3846/btp.2018.03.

Arif, S. (2018). Transformational Leadership and Organizational Performance The Mediating Role of Organizational Innovation. SEISENSE Journal of Management, 1(3), 201-219. https://doi.org/10.5281/zenodo.1306335.

Avolio, B.J. (1999). Full Leadership Development: Building the Vital Forces in Organizations. Thousand Oaks: CA Sage. 
Baron, Sherrod, A.M., Aboshaiqah, Hamdan-Mansour, A.E. and Alkhaibary (2014) 'Nurses" Perception of Managers" Leadership', American Journal of Nursing, vol. VOL III, no.1., pp. 57-62.

Bass Bernard M., R. R. E. (2006). Transformational Leadership (2nd Ed.). London: Lawrence Erlbaum Associates publishers.

Bass, B. M. (1985). Leadership and Performance beyond Expectations. New York, Free Press.

Bass, B. M. (1990). From Transactional to Transformational Leadership: Learning to Share the Vision. Organizational Dynamics, 18(3), 19-32.

https://doi.org/10.1016/0090-2616 (90) 90061-S

Bass, B. M. (1997). Does the transactional-transformational leadership paradigm transcend organizational and national boundaries? American Psychologist, 52(2), 130-139. https://doi.org/10.1037/0003-066X.52.2.130

Bass, B. M., \& Avolio, B. J. (1994). Improving organizational effectiveness through transformational leadership. Thousand Oaks, CA: Sage.

Bass, B. M., Avolio, B. J., Jung, D. I., \& Berson, Y. (2003). Predicting unit performance by assessing transformational and transactional leadership. Journal of Applied Psychology, 88(2), 207-218. https://doi.org/10.1037/00219010.88.2.207

Bono, J. E., \& Judge, T. A. (2004). Personality and Transformational and Transactional Leadership: A Meta-Analysis. Journal of Applied Psychology, 89(5), 901-910. https://doi.org/10.1037/0021-9010.89.5.901

Buciuniene, I, \& Skudience, V. (2008). Impact of leadership styles on employees' organizational commitment in Lithuanian manufacturing companies. SEE Journal. 18, 57-65.

Burns, J.M. (1978) Leadership, New York, 2nd edition, Harper and Row.

Conger, J. a., \& Kanungo, R. N. (1987). Toward a Behavioral Theory of Charismatic Leadership in Organizational Settings. The Academy of Management Review, 12(4), 637. https://doi.org/10.2307/258069

Corvellec, H. (2011). New rhetoric and Organization Studies. In B. Binet,Eduard; Czarniawska (Ed.), Second Conference on Rhetoric and Narratives in Management Research (pp. 31-48). Barcelona.

Dinh, J. E., Lord, R. G., Gardner, W. L., Meuser, J. D., Liden, R. C., \& Hu, J. (2014). Leadership theory and research in the new millennium : Current theoretical trends and changing perspectives. The Leadership Quarterly, 25(1), 36-62. https://doi.org/10.1016/j.leaqua.2013.11.005

Garcýa-Morales, V.J., Llorens-Montes, F.J. and Verdu Jover, A.J. (2008). The Effects of Transformational Leadership on Organizational Performance through Knowledge and Innovation. British Journal of Management. 19(4): 299-319. 
Hargis, M. B., Wyatt, J.D., Piotrowski, C. (2001). Developing Leaders: Examining the Role of Transactional and Transformational Leadership across Contexts Business. Organization Development Journal 29 (3): 51-66.

Hunt, J. G. (1999). Transformational/charismatic leadership's transformation of the field: An historical essay. The Leadership Quarterly, 10(2), 129-144.

doi:10.1016/S1048-9843(99)00015-6

Jing, F. F., \& Avery, G. C. (2008). Missing Links In Understanding The Relationship Between Leadership And Organizational Performance. International Business \& Economics Research Journal, 7(5), 67-78. https://doi.org/10.19030/iber.v7i5.3256

Johns, H. E., \& Moser, H. R. (2001). From Trait to Transformational Leadership.pdf. Education, 110(1).

Judge, T. A., \& Piccolo, R. F. (2004). Transformational and Transactional Leadership: A Meta-Analytic Test of Their Relative Validity. Journal of Applied Psychology, 89(5), 755-768. https://doi.org/10.1037/0021-9010.89.5.755

Judge, T.A. \& Bono, J.E. (2000). Personality and transformational and transactional leadership: A meta-analysis. Journal of Applied Psychology, 89, 901910.

Jung, D. I., \& Sosik, J. J. (2002). Transformational Leadership in Work Groups: The Role of Empowerment, Cohesiveness, and Collective-Efficacy on Perceived Group Performance. Small Group Research, 33(3), 313336.http://dx.doi.org/10.1177/10496402033003002

Kehinde A .1, Hassan Banjo A. (2014). Test of the Impact of Leadership Styles on Employee Performance: A Study of Department of Petroleum Resources. International Journal of Management Sciences.

Keller, R.T (1992) Transformational leadership and the Development of Research and Development Project Groups. Journal of Management. 489 - 501

Kuhnert, Karl W., Lewis, P. (1987). Transactional and Transformational Leadership: A Constructive/Developmental Analysis. Academy of Management Review. https://doi.org/10.2307/258070

Li, H., Sajjad, N., Wang, Q., Ali, A. M., Khaqan, Z., \& Amina, S. (2019). Influence of transformational leadership on employees' innovative work behavior in sustainable organizations: Test of mediation and moderation processes. Sustainability (Switzerland), 11(6), 1-21. https://doi.org/10.3390/su11061594

Lowe, K. B., \& Gardner, W.L. (2000). Ten years of The Leadership Quarterly: Contributions and challenges for the future. Leadership Quarterly, 11, 459-514. 
Manzoor, F., Wei, L., Nurunnabi, M., Subhan, Q. A., Shah, S. I. A., \& Fallatah, S. (2019). The impact of transformational leadership on job performance and CSR as mediator in SMEs. Sustainability (Switzerland), 11(2), 1-14.

https://doi.org/10.3390/su11020436

Mccleskey, J. A. (2014). Situational, Transformational, and Transactional Leadership and Leadership Development. Journal of Business Studies Quarterly, 5(4). Retrieved from https://pdfs.semanticscholar.org/f584/807652909f1c90c5a647ebcea142d2260d9a. pdf

Mehra, A., Smith, B. R., Dixon, A. L., \& Robertson, B. (2006).Distributed leadership in teams: The network of leadership perceptions and team performance. The Leadership Quarterly, 17(3), 232-245.

Meindl, J. (1993). Reinventing Leadership A Radical Socio psychological approach. In Social Psychology in Organizations: Advances in Theory and Practice (pp. 120-195).

Nemanich, L. A., \& Keller, R. T. (2007). Transformational leadership in an acquisition: A field study of employees. The Leadership Quarterly, 18(1), 49-68. http://dx.doi.org/10.1016/j.leaqua.2006.11.003

Northouse, P.G. (2015). Leadership: Theory and practice (6th Ed.). Thousand Oaks, CA: Sage Publications

Odumeru, J. A., \& Ogbonna, I. G. (2013). Transformational vs. transactional leadership theories: Evidence in literature. International Review of Management and Business, 2(2), 355-361. Retrieved from http://www.ibima.org/pub/journals/IBIMA-BR/IBIMABR.html\%5Cnhttp://www.irmbrjournal.com/papers/1371451049.pdf

Ojokuku, M. M., Odetayo, T. A., \& Sajuyigbe, A. S. (2012). Impact of Leadership Style on Organizational Performance : A Case Study of Nigerian Banks. American Journal of Social and Management., 1(4), 202-207.

Piccolo, R.F, and Colquitt, J.A. (2006) Transformational Leadership and Job Behaviour: The Mediating Role of Core Job Characteristics. Academy of Management Journal. 327 - 340

Randall, D. M. (2012). Leadership and the use of power: Shaping an ethical climate. The Journal of Applied Christian Leadership, 6(1), 28-35.

Rasool, H. F., Arfeen, I. U., Mothi, W., \& Aslam, U. (2015). Leadership styles and its impact on employee's performance in health sector of Pakistan. University Research Journal, 5(1)

Riad Ahmad Mohammed Abazeed. (2018). Impact of Transformational Leadership Style On Organizational Learning in the Ministry of Communication and Information Technology in Jordan. International Journal of Business and Social Science, 1(9), 118-129. 
Robbins, S. P. and Coulter, M. (2007) Management (9th Ed.). London: PrenticeHall

Rubin, R.S., Munz, D.D and Bommer, W.H. (2005) Leading from Within: effects of Emotional Recognition and Personality on transformational Leadership Behaviour. Academy of Management Journal. 845 - 858

Russell, J. (2017). A Meta-analysis: The Full Range of Leadership Model Impacting Policing Organizations. Welden University. Retrieved from http://scholarworks.waldenu.edu/dissertations

Tahir, H. (2015). Leadership style and Organizational Performance: A Comparative study between Transformational and Transactional Leadership styles. Journal of Business Studies, 11(2), 257-274.

Tsigu, G. T., \& Rao, D. P. (2015). Leadership styles: their impact on job outcomes in Ethiopian banking industry. Journal of Business Economics \& Management Research, 5(2), 41-52.

Vigoda-Gadot, E. (2007). Leadership style, organizational politics, and employees' performance. Personnel Review, 36(5), 661-683.

https://doi.org/10.1108/00483480710773981

Waldman, D. A., Bass, B. M., \& Yammarino, F. J. (1988). Adding to LeaderFollower Transactions: The Augmenting Effect of Charismatic Leadership. Center for Leadership Studies.

Wang, F., Chich-Jen, S., \& Mei-Ling, T. (2010). Effect of leadership style on organizational performance as viewed from human resource management strategy. African Journal of Business Management, 4(18), 3924-3936.

Warrilow, S (2012) Transformational Leadership Theory-The four key Components in Leading Change \& Managing Change. [Retrieved 15/03/2013].

http://EzineArticles.com/?expert=Stephen_Warrilow

Yaslioglu, M. M., \& Selenay Erden, N. (2018). Transformational Leaders in Action: Theory Has Been There, But What About Practice? IUP Journal of Business Strategy, 15(1), 42-53. Retrieved from https://search.ebscohost.com/login.aspx?direct=true\&db=bsu\&AN=128932995\&sit $\mathrm{e}=$ eds-live\&scope=site

Yousef, D.A. (2000). Organizational Commitment: A Mediator of the Relationships of Leadership Behavior with Job Satisfaction and Performance in a Non-Western Country. Journal of Managerial Psychology, 15(1), 6-24.

Yukl, G. (1999). An Evaluation of the Conceptual Weaknesses in Transformational and Charismatic Leadership Theories. Leadership Quarterly. 10(2), 285-305. 